\title{
PARROTS, PEOPLE AND PLANTS: URBAN TREE REMOVAL AND HABITAT LOSS FOR THE ENDANGERED SWIFT PARROT, LATHAMUS DISCOLOR
}

\author{
by Andrew B. Hingston and Marta Piech
}

(with one appendix)

\begin{abstract}
Hingston, A.B. \& Piech, M. 2011 (9:xii): Parrots, people and plants: urban tree removal and habitat loss for the endangered Swift Parrot, Lathamus discolor. Papers and Proceedings of the Royal Society of Casmania 145: 1-4. https://doi.org/10.26749/rstpp.145.1 ISSN 0080-4703. School of Geography and Environmental Studies, University of Tasmania, Private Bag 78, Hobart, Tasmania 7001, Australia (ABH*, MP). *Author for correspondence. Email: hingston@utas.edu.au
\end{abstract}

Swift Parrots, Lathamus discolor, breed predominantly in southeastern Tasmania, including around the city of Hobart. While breeding, they feed mostly on the nectar and pollen of Tasmanian Blue Gum, Eucalyptus globulus, and Black Gum, E. ovata, trees. Swift Parrots are regularly observed foraging on these floral products in the Hobart suburb of Mt Nelson, where the trees produce more flowers than those in adjacent bushland. To investigate trends in the availability of food for Swift Parrots breeding near Hobart, we surveyed people who live in Mt Nelson to ascertain the extent of removal of large eucalypt trees from their properties. The 294 respondents to our questionnaire reported the presence of 263 large E. globulus and 109 large E. ovata on their properties. However, respondents also stated that they had removed 88 large E. globulus and 25 large E. ovata trees in the past five to 10 years, and intended felling a further 13 large E. globulus and 15 large $E$. ovata trees in the near future. This represents the removal of almost $30 \%$ of large trees of both species within a decade, and suggests a decline in foraging habitat for Swift Parrots while breeding near Hobart.

Key Words: birds, threatened species management, urban ecology, wildlife, Swift Parrots, Lathamus discolor; Tasmanian Blue Gum, Black Gum, Eucalyptus globulus, Eucalyptus ovata.

\section{INTRODUCTION}

The Swift Parrot, Lathamus discolor (Shaw, 1790), is an endangered species ofbird that breeds exclusively in Tasmania, mostly along the southeastern coast (Hindwood $\&$ Sharland 1963, Brown 1989, Brereton 1996). This area encompasses the Tasmanian capital city of Hobart, where nesting has been observed in surrounding bushland (Brown 1989, Brereton 1997).

During their breeding season, Swift Parrots rely predominantly on the nectar and pollen of Tasmanian Blue Gum, Eucalyptus globulus Labill., and Black Gum, E. ovata Labill., for food (Brown 1989, Brereton 1996, 1997, Gartrell et al. 2000, Gartrell \& Jones 2001, Hingston et al. 2004). The reproductive success of Swift Parrots appears to be limited by food availability at this time, with fewer chicks fledged during seasons of poor flowering in E. globulus (Brereton 1996). During such seasons, the birds become more reliant on the smaller quantities of food produced by the flowers of E. ovata (Brown 1989).

Swift Parrots commonly forage from flowers of E. globulus and $E$. ovata in the outer Hobart suburb of Mt Nelson during their breeding season (Brereton 1996, 1997, Gartrell 2001, Hingston 2002, 2007). For example, 4-5\% of the entire wild population of Swift Parrots was observed foraging in Mt Nelson throughout spring 2002 (Hingston 2007). Both E. globulus and E. ovata occur within the suburb, as well as in bushland around Mt Nelson (Hingston \& Piech 2011). However, flower production on large trees of both species within suburban Mt Nelson is more prolific than on large trees in the surrounding bushland, apparently because suburban trees have denser canopies and less fire damage (Hingston \& Piech 2011). Consistent with this, Swift Parrots appear to forage more often in these suburban trees than in nearby bushland trees (A. Hingston pers. obs.).
To better understand trends in the availability of eucalypt nectar and pollen for Swift Parrots breeding near Hobart, we investigated the extent of recent and projected removal of large E. globulus and E. ovata trees from suburban $\mathrm{Mt}$ Nelson.

\section{METHODS}

An anonymous survey was conducted among Mt Nelson residents in autumn 2008 to obtain information regarding large eucalypt trees on residential properties. All households of Mt Nelson, excluding flats, $(n=830)$ received a letter and questionnaire (appendix 1 ) with a return addressed envelope in their letterboxes.

The main purpose of the survey was to examine whether people have had, or intend to have, large E. globulus and $E$. ovata trees removed from their property. Large trees were defined as having a circumference greater than $2 \mathrm{~m}$ at $1.3 \mathrm{~m}$ above the ground. Questions in the survey were designed to elicit the following information: the ownership status of the property; the presence of large eucalypts on the property; any removal of large eucalypts in the past five to 10 years; and any intended eucalypt removal and reasons for that removal (appendix 1).

\section{RESULTS}

Two hundred and ninety-four completed responses were received. This represented a return of $35 \%$ of the 830 questionnaires originally dispatched. The majority of respondents $(95 \%)$ were the owners of a Mt Nelson property, and only $5 \%$ were renting. 


\section{Presence of large eucalypts}

The 294 respondents were divided almost equally between properties with large eucalypts $(n=144)$ and those without ( $n$ $=150$ ). Of the 144 respondents with large eucalypts on their properties, $54.9 \%(\mathrm{n}=79)$ said E. globulus was present while $25.7 \%(\mathrm{n}=37)$ reported the absence of this species. Large trees of $E$. ovata were reported less often, with only $21.5 \%$ ( $n=31$ ) of the 144 respondents stating their presence and $43.7 \%(\mathrm{n}=63)$ their absence. The remaining respondents were unsure if the large eucalypts on their properties were of these species.

Most properties with large $E$. globulus or $E$. ovata had small numbers of these, and none had more than 20 of either species. Of the 79 respondents who reported large E. globulus on their property, $41.8 \%(\mathrm{n}=33)$ said they had only one of these, $22.8 \%(\mathrm{n}=18)$ had two and $11.4 \%$ $(\mathrm{n}=9)$ had three. Only $24.1 \%(\mathrm{n}=19)$ of the properties with large $E$. globulus trees had more than three. Of the 31 respondents who reported large $E$. ovata on their property, $38.7 \%(\mathrm{n}=12)$ said they had only one and $32.3 \%(\mathrm{n}=$ $10)$ had two. Properties with more than two large $E$. ovata trees were rather scarce $(29.0 \% ; \mathrm{n}=9)$.

The residents reported totals of 263 large E. globulus and 109 large E. ovata trees on the 294 properties. However, these are probably underestimates because, of the 144 respondents who stated that they had large eucalypts on their property, $19.4 \%(\mathrm{n}=28)$ were unsure if they had E. globulus and $34.7 \%(\mathrm{n}=50)$ were unsure if they had $E$. ovata.

\section{Recent tree removal}

A large proportion of respondents said that large trees had been removed from their properties in the past five to 10 years. While $56.8 \%$ of the 294 respondents $(n=167)$ reported that no large trees had been removed, 38.4\% ( $\mathrm{n}=$ 113 ) stated that some trees had been felled in this period. A small percentage of people $(4.8 \% ; n=14)$ were not sure if large trees had been removed in the past five to 10 years.

More $E$. globulus than $E$. ovata have been cut down from the respondents' properties in the past five to 10 years. Among the 113 respondents who stated that large trees had been removed from their properties, 35.4\% $(n=40)$ said this involved $E$. globulus while only $14.2 \%(\mathrm{n}=16)$ said $E$. ovata was removed. Most removals involved just one tree per property, with this being the case for $65.0 \%$ ( $\mathrm{n}=26$ ) of properties from which $E$. globulus was removed and $56.2 \%(\mathrm{n}=9)$ of properties from which E. ovata was removed. However, this still represents the felling of $25.1 \%$ ( $\mathrm{n}=88$ ) of the E. globulus, and $18.7 \%(\mathrm{n}=25)$ of the $E$. ovata, trees present five to 10 years ago. It is likely that greater numbers of trees of these species have been cut down because, of the 113 respondents who stated that they had removed large trees, $33.6 \%(\mathrm{n}=38)$ were unsure if this included $E$. globulus and $37.2 \%(\mathrm{n}=42)$ were unsure if this included $E$. ovata.

Rates of removal of the two species of eucalypt reflected their proportional abundances across the respondents' properties. There was no significant preference for removal of one species over another $\left(\chi^{2}=1.7, P>0.1\right)$.

\section{Future tree removal}

Most residents who responded to the questionnaire stated that they had no intention of removing any large trees in the future. This was the case for $73.8 \%(\mathrm{n}=217)$ of respondents. However, $15.6 \%(n=46)$ said that they were planning on some tree felling, and $10.6 \%(n=31)$ were not sure whether they would have trees cut down in the future.

Within the group of 46 residents who declared future tree removal, more than half said there would not be any E. globulus or $E$. ovata among the trees to be felled (n = 24 in both cases). However, $21.7 \%$ of these respondents $(n=10)$ intended cutting down E. globulus and 19.6\% (n =9) intended felling $E$. ovata. They intended removing up to three large trees of each species, equating to $4.9 \%$ $(\mathrm{n}=13)$ of the $E$. globulus and $13.8 \%(\mathrm{n}=15)$ of the $E$. ovata currently present. These figures indicate no significant preference for future removal of one species over another $\left(\chi^{2}=0.038, P>0.8\right)$. However, it is likely that more trees of these species will be removed because, of the respondents who stated that they would have large eucalypts felled, $26.1 \%$ ( $\mathrm{n}=12$ ) were unsure if this would include $E$. globulus and $28.3 \%(n=13)$ were unsure if this would include $E$. ovata.

\section{Reasons for eucalypt removal}

When asked about the reasons for tree removal, some respondents did not answer the question and some gave more than one answer; hence the numbers below reflect the frequency at which a particular reason was given. The most common reason $(n=31)$ for future tree removal was the anticipated house damage caused by falling limbs, as well as fire. Another rationale was the inconvenience that trees may cause $(n=12)$; such as block the view, clog the gutters, make a mess, use too much water or spread roots. Tree sickness and its partial death or damage was also commonly given as a reason for removal $(n=10)$.

\section{DISCUSSION}

The responses of $\mathrm{Mt}$ Nelson residents to this survey indicate that there are hundreds of large $E$. globulus and $E$. ovata trees on residential properties within the suburb. Respondents reported the presence of 263 E. globulus and 109 E. ovata trees with circumferences of over $2 \mathrm{~m}$ at $1.3 \mathrm{~m}$ above the ground. However, these figures almost certainly underestimate the total numbers because they represent the numbers from only $35 \%$ of residential properties, and many of the respondents who stated that they had large eucalypts on their property were unsure if they had $E$. globulus or E. ovata. The abundance of these trees within the suburb, together with their propensity to flower profusely (Hingston \& Piech 2011), results in the production of large quantities of nectar and pollen that provides potential food sources for Swift Parrots. Accordingly, Swift Parrots often use these resources in suburban Mt Nelson during their breeding season (Brereton 1996, 1997, Gartrell 2001, Hingston 2002, 2007).

The residents' responses indicate that these resources are likely to be declining. On the respondents' properties, at least $25.1 \%$ of the large $E$. globulus and $18.7 \%$ of the $E$. ovata trees have been removed in the past five to 10 years. This removal is likely to continue because respondents 
indicated that a further $3.7 \%$ of the large E. globulus, and $11.2 \%$ of the large $E$. ovata, trees that were present five to 10 years ago will be felled soon. Hence, almost $30 \%$ of large trees of both species have either been removed in the past few years, or soon will be. This figure is likely to be an underestimate because many felled trees were not identified to species level, and therefore not included in these figures. The reasons given for tree removal were many and varied, but it is clear that people will continue to desire, and often need, to remove large trees from residential areas. This removal of large trees will, of course, be offset to some degree by continued growth in the sizes of remaining trees and the tecruitment of new trees in the suburb. Rates of growth and recruitment will need to be quantified if we are to determine the maximum rate of tree removal that can occur without a net loss of foraging habitat for Swift Parrots in Mt Nelson.

It is unclear what effect any decline in food availability in Mt Nelson for Swift Parrots will have on their population. Because reproductive success of Swift Parrots appears to be limited by food availability during the breeding season (Brereton 1996), any decline in food availability across their breeding range is potentially detrimental. However, Swift Parrots attracted to urban areas can suffer high rates of mortality from collisions with human artefacts such as windows and fences (Brown 1989, Saunders et al. 2007), and this might become less frequent if food availability declines in urban areas such as Mt Nelson.

\section{ACKNOWLEDGEMENTS}

We thankDr Emma Pharo for guidance on this project, and the many $\mathrm{MtNelson}$ residents who completed the questionnaire. This research was carried out under a University of Tasmania ethics clearance (Ethics Reference Number H10037).

\section{REFERENCES}

Brereton, R. 1996: The Swift Parrot Lathamus discolor in south-east Tasmania. Conservation Research Statement. Project No. 230. Australian Nature Conservation Agency, Endangered Species Program, Canberra: $37 \mathrm{pp}$.
Brereton, R. 1997: Management prescriptions for the Swift Parrot in production forests. Report to Tasmanian RFA Environment and Heritage Technical Committec. February 1997. Parks and Wildlife Service, Department of Environment and Land Management, Hobart: $52 \mathrm{pp}$.

Brown, P.B. 1989: The Swift Parrot Lathamus discolor: a report on its ecology, distribution and status, including management considerations. July 1989. Department of Lands Parks and Wildlife, Tasmania: $103 \mathrm{pp}$.

Gartrell, B.D. 2001: Nutritional and physiological constraints on reproduction in the endangered Swift Parrot Lathamus discolor. Unpublished PhD thesis, University of Tasmania, Hobart.

Gartrell, B.D. \& Jones, S.M. 2001: Eucalyptus pollen grain emptying by two Australian nectarivorous psittacines. Journal of Avian Biology 32: 224-230.

Gartrell, B.D., Jones, S.M., Brereton, R.N. \& Astheimer, L.B. 2000: Morphological adaptations to nectarivory of the alimentary tract of the Swift Parrot Lathamus discolor. Emu 100: 274-279.

Hindwood, K.A. \& Sharland, M. 1963: The Swift Parrot. Emu 63: $310-326$.

Hingston, A.B. 2002: Pollination ecology of Eucalyptus globulus subsp. globulus and Eucalyptus nitens (Myrtaceae). Unpublished PhD thesis, University of Tasmania, Hobart.

Hingston, A.B. 2007: The potential impact of the Large Earth Bumblebee Bombus terrestris (Apidae) on the Australian mainland: Lessons from Tasmania. The Victorian Naturalist 124: $110-115$.

Hingston, A.B. \& Piech, M. 2011. Eucalypt flower production in the suburbs and bush: implications for the endangered Swift Parrot Lathamus discolor. Pacific Conservation Biology 17: in press.

Hingston, A.B., Gartrell, B.D. \& Pinchbeck, G. 2004: How specialized is the plant-pollinator association between Eucalyptus globulus ssp. globulus and the Swift Parrot Lathamus discolor? Austral Ecology 29: 624-630.

Saunders, D., Brereton, R., Tzaros, C., Holdsworth, M. \& Price, R. 2007: Conservation of the Swift Parrot Lathamus discolor - management lessons for a threatened migratory species. Pacific Conservation Biology 13: 111-119.

(accepted 4 July 2011) 


\section{APPENDIX 1}

Note before you start: For the purpose of this particular study, a tree is considered to be large if its circumference (measured at $1.3 \mathrm{~m}$ above ground) is $2 \mathrm{~m}$ or more.

Q1. Please tick one:

$\square$ I am the owner-occupier of a Mt Nelson property

I am renting a Mt Nelson property

Q2. Do you have any large eucalyptus trees on your property? $\square$ Yes (Go to Question 3) No (Go to Question 7)

Q3. Do you have any large Blue Gums (Eucalyptus globulus) on your property?

D Yes (Go to Question 4)

Do (Go to Question 5)

II'm not sure (Go to Question 5)

Q4. How many large Blue Gums (Eucalyptus globulus) do you have on your property (if the number is more than 10 , can you estimate how many?)

Q5. Do you have any large Black Gums (Eucalyptus ovata) on your property?

घ Yes (Go to Question 6)

Do (Go to Question 7)

$\square$ I'm not sure (Go to Question 7)

Q6. How many large Black Gums (Eucalyptus ovata) do you have on your property (if the number is more than 10 , can you estimate how many?)

Q7. Have you had any large trees removed from your property in the past $5-10$ years?

- Yes (Go to Question 8)

$\square$ No (Go to Question 9)

Q8. How many large trees have been removed from your property in the past $5-10$ years and what species were they? (i.e. $1 \times$ Blue Gum, approx. $4 \times$ Black Gum, $1 \times$ name unknown, etc.)

(If you're not sure what the exact number was, please estimate how many. If you don't know the name of the species, write "name unknown")

Q9. Are you planning on having any large trees removed from your property in future?

$\square \quad$ Yes (Go to Questions $10 \& 11$ )

$\square$ No (Go to Question 12)

$\square$ Not sure (Go to Question 12)
Q10. Can you name the number and species of the large trees to be removed? (i.e. 1 x Blue Gum)

Q11. Briefly state the reason(s) why you want to have the tree $(s)$ removed.

Q12. It would help to know your location. If you are not comfortable with providing your street number, then could you please provide your street name and tick one of the areas below.

Address

Areas

$\square$ The Bends

- Mt Nelson Primary School area (between the Mt Nelson Water Reservoir at the top of Bend 7 and Mt Nelson Store)

$\square \quad$ Signal Station area (between Mt Nelson Tavern and Signal Station)

घ Mt Nelson Oval area (between Mt Nelson Tavern and Mt Nelson Store, including Rialannah Rd)

$\square$ Hobart College area (between Mt Neson Store and beginning of Proctors Rd)

Q13. Please tick the box below if you would like a summary of the results forwarded to you. Please note that if you tick the box, you need to provide your postal address (see Question 12)

$\square \quad$ Yes, I would like to receive a summary of the results

Thank you for completing the questionnaire.

Please forward the questionnaire to the following address using the self-addressed envelope:

Attn: Marta Piech,

School of Geography and Environmental Studies, University of Tasmania,

Private Bag 78, Hobart, Tasmania 7001. 